\title{
Health care for the elderly in Japan: medicine and welfare in an aging society facing a crisis in long term care
}

\author{
Yuzo Okamoto
}

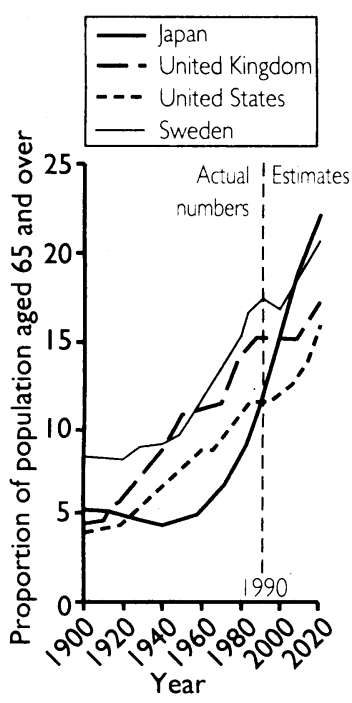

FIG $1-$ Actual and projected proportions of populations of fapan, United Kingdom, United States, and Sweden aged 65 and over (1900-2020).

(Sources of data for Fapan: fapanese Statistics Bureau; Fapanese General Affairs Agency; Insitute of Population Problems, Fapanese Ministry of Health and Welfare. Source of data for other countries: United Nations Population Studies)

Department of Internal Medicine and Home Care, Hannan Chuo Hospital, 3-3-28 Minamishinmachi, Matsubara-shi, Osaka 580, Japan

Yuzo Okamoto, chief of staff

$B M F$ 1992;305:403-5
How medical care and social welfare services for the elderly should be provided is now a common concern among all advanced industrialised nations. In demographic terms an advanced industrialised nation implies an aging society. Hence the provision of medical and welfare services specifically for the elderly is integral in the development of an industrialised society.

The rapid economic growth in Japan since the second world war has been accompanied by improved health standards of the Japanese people. The average life expectancies of men and women in Japan are the highest in the world $(75.9$ years for men, 81.8 years for women (1990 data)), with the result that $11.6 \%$ of the population of Japan is over 65 . Owing to the continuous migration of younger people from the country to the cities during the period of rapid economic growth in the 1950s and 1960s, in some rural areas over a quarter of the population is over 65 . It is estimated that by about 2025 the proportion nationally will be $23 \cdot 4 \%$ (see fig 1).

In addition to the question of who should bear the rapidly increasing cost of medical care for elderly people is the question of who should provide long term care for disabled members of the group. The lack of sufficient facilities providing excellent care and the severity of disability of many elderly people have strained relations between older and younger generations. The excessive family burden has led to crises in many families, resulting in increased public awareness of the problem.

\section{Mechanisms of a rapidly aging society}

The major causes of the rapidly aging population in Japan are the improvement of living standards and increased usage of medical care. These have lowered the death rates for all age groups caused by tuberculosis and other infectious diseases and resulted in sharp falls in mortality among infants, adolescents, and young adults. Moreover, since the 1960 s death rates among middle aged and elderly people have also shown a steep decline and life expectancies of all age groups have risen substantially. These improvements may be attributed to social, environmental, and biological changes.

Several factors have contributed to the remarkable improvement in health in Japan. The availability of medical services for all was achieved by the introduction of compulsory national health insurance in the 1960 s. Encouraging people to eat high protein diets and the promotion of health education, which emphasises restricting salt (from $13.5 \mathrm{~g}$ daily in 1975 to $11.7 \mathrm{~g}$ daily in 1987), ${ }^{1}$ have helped reduce mortality from cerebrovascular disease. ${ }^{2}$ Corrected mortality (based on the European population model in 1976) ${ }^{3}$ for cerebrovascular disease was $271 \cdot 8 / 100000$ population in 1955 and $118 \cdot 6 / 100000$ in 1985 . The mortality from cardiovascular disease has also been kept low in Japan by traditional low energy, low fat diets (table I). Corrected mortality for cardiovascular disease was $113 \cdot 2 / 100000$ in 1955 , increasing slightly to $123.9 / 100000$ in $1985 .^{56}$

Given this background, population aging in Japan occurred very rapidly. The proportion of the total population who were aged 65 or over increased from $5 \cdot 3 \%$ in 1955 to $10 \cdot 3 \%$ in 1985 (fig 1 ).

TABLE I-Daily dietary intake per person in fapan, United Kingdom, and United States

\begin{tabular}{|c|c|c|c|c|c|}
\hline & \multirow{2}{*}{$\begin{array}{c}\text { Energy } \\
(\mathrm{MJ})\end{array}$} & \multirow{2}{*}{$\begin{array}{l}\text { Starchy } \\
\text { food } \\
(\%)\end{array}$} & \multicolumn{2}{|c|}{ Protein $(\mathrm{g})$} & \multirow{2}{*}{$\begin{array}{l}\text { Fat } \\
\text { (g) }\end{array}$} \\
\hline & & & Total & Animal & \\
\hline Japan & $11 \cdot 0$ & $46 \cdot 4$ & $87 \cdot 9$ & $45 \cdot 1$ & $82 \cdot 4$ \\
\hline United Kingdom & $14 \cdot 2$ & $30 \cdot 9$ & $95 \cdot 3$ & $57 \cdot 7$ & $167 \cdot 2$ \\
\hline United States & 14.8 & $20 \cdot 7$ & $106 \cdot 6$ & 74.9 & 177.6 \\
\hline
\end{tabular}

Source: Tsuneta Yano Memorial Society. ${ }^{+}$

\section{Medical care system in Japan}

Japan has a compulsory national health service system that is financed by employer contributions, individual contributions, and taxes through non-profit insurance funds. As of April 1961 the system has been operating to guarantee coverage by some form of medical care insurance to everyone. Each of these insurance plans has its own insurer and type of member and different premium and cost sharing rates. The insurance system has had some problems-for example, in the heavy use of pharmaceutical products and long average hospital stay of patients. ${ }^{78}$

\section{Problems inherent in care systems for the elderly}

When the national health insurance system started cost sharing for an elderly, dependent person was relatively high $(50 \%)$. Although elderly people were those who most needed medical care services, most of them either were pensioners or were retired with little or no income, so that their cost sharing ability was limited. Hence, although the sickness rate of elderly people was high, their rate of receiving medical care was lower than that of other groups, including children. This continued until the 1970 s, when the government made all people over 65 eligible for free medical care. With the increase in numbers of elderly people in the population, however, the cost of providing free medical care rose substantially. Thus in 1983 cost sharing for patients over 65 was reinstated, though contributions were kept much lower than those from other groups. Overall these policies increased the use of medical care services by elderly people, so that in 1988 elderly people accounted for $26.7 \%$ of the total national expenditure on medical care. In Japan elderly people have also become more willing to use medical care services, which is a further, major factor in the increased life expectancy (fig 2). 


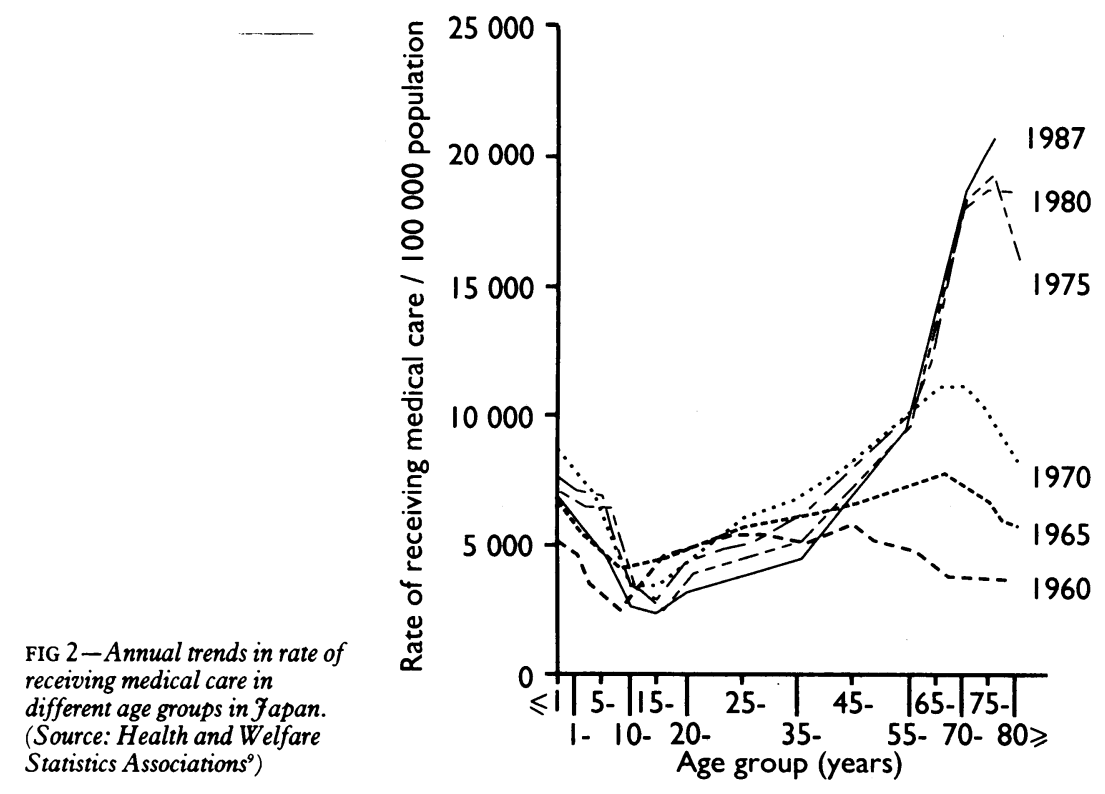

The effect of the medical care service on the standard of health of elderly people has been remarkable. People over 65 in Japan had low living standards and poor nutrition in their early years and did not benefit constitutionally from the substantial postwar improvement. Nevertheless, they now have lower mortality and longer life expectancies than earlier generations. Longer life expectancy as a result of better medical care, however, has meant that most hospitals in Japan have beds occupied for long periods by disabled elderly patients. For example, in 1987 about $29 \%$ of all $1 \cdot 11$ million inpatients (excluding the mentally ill) had admissions exceeding six months (table II). Of these patients, 69\% (221710) were aged 65 and over, of whom $40 \%$ were in hospital for cerebrovascular disease. ${ }^{1}$ During 1964-84 there was no significant decline in the incidence of cerebrovascular disease in the over 70 s, ${ }^{2}$ so that since the early 1980 s the long term care of elderly people has become a serious problem.

TABLE II -Distribution of all inpatients ( $n=1 \cdot 11$ million) in Fapan in 1987 by duration of hospital stay (data exclude patients admitted for psychiatric disorders)

\begin{tabular}{lccccccccc}
\hline & \multicolumn{10}{c}{ Inpatient stay } & \\
\cline { 2 - 8 } & $\begin{array}{c}514 \\
\text { Days }\end{array}$ & $\begin{array}{c}15-30 \\
\text { Days }\end{array}$ & $\begin{array}{c}\text { Months } \\
\text { 1-3 }\end{array}$ & $\begin{array}{c}3-6 \\
\text { Months }\end{array}$ & $\begin{array}{c}6 \text { Months } \\
\text { to 1 year }\end{array}$ & $\begin{array}{c}1-3 \\
\text { Years }\end{array}$ & $\begin{array}{c}>3 \\
\text { Years }\end{array}$ & Unknown & Total \\
\hline \% Of inpatients & $27 \cdot 1$ & $13 \cdot 1$ & $20 \cdot 4$ & $10 \cdot 1$ & $8 \cdot 0$ & $11 \cdot 2$ & $9 \cdot 8$ & 0.3 & $100 \cdot 0$ \\
\hline
\end{tabular}

\section{Problem of long term care for the elderly}

"Social admissions" of elderly people during the 1970 s and 1980 s not only meant that some critically ill patients could not be admitted but also caused extra work for nurses and jeopardised efficiency. The main reasons that these elderly patients could not return home included lack of family care givers, lack of home help services, and lack of space. Administrators, however, ignored these problems. The numbers of nursing homes remained static whereas demand for long term care of elderly patients was increasing. Nursing home beds totalled only 11280 in 1970 and 80385 in 1980 . In order to satisfy the growing need for long term care numbers of beds were increased by establishing new hospitals, converting mental hospitals into geriatric facilities, and utilising private hospitals that hitherto had been providing substandard care.

In recent years government at all levels has taken a more active role in encouraging the development of facilities for the long term care of disabled elderly people. There are currently three types of facilities. ${ }^{10}$ The first, "hospitals for the elderly" (123355 beds
(1989 data)), are geriatric hospitals which are authorised to have fewer doctors and nurses than acute care hospitals. The second type are "special nursing homes for the aged," and currently there are 172019 beds in such establishments in Japan. These are welfare institutions for people who need constant care. Staffing is at a level of one full time or part time physician, three nurses, and 22 nursing assistants per 100 residents. The third type of facility, "health facility for the elderly," has been introduced only in the past seven years. There are to date only 47811 beds in these facilities, but this type of institution is targeted for expansion. These are rehabilitation facilities with stays limited to three months for patients who need functional training and nursing care but not medical treatment. Required staffing is one full time physician, eight nurses, and 20 nursing assistants per 100 patients.

Plainly there is still a severe shortage of long term care facilities for elderly patients in Japan, the lack of rehabilitation services making things worse. Even in 1985 only $30 \%$ of general hospitals had a rehabilitation department. " As a result some $34 \%$ of patients in long term care facilities in Japan are bedbound as compared with $6.5 \%$ in the United States and $4.2 \%$ in Sweden. ${ }^{12}$

These elderly patients either are too heavy a burden for their families or do not have families who can care for them. Many have ended up in decrepit, understaffed hospitals, where treatment may be grossly inadequate. For example, patients with dementia may be tied to their beds and overmedicated.

Factors underlying the unwillingness or inability of families to care for disabled elderly relatives include the dramatic changes in social structure that accompanied the rapid development of a highly industrialised society during the 1960s and 1970s. These changes included a rapidly declining number of workers in primary industry (for example, agriculture), a decline in the custom for elderly people to live with their children (fig 3), the nuclearisation of the family, and the growing number of middle aged women in the labour force. Of the 600000 bedridden people in Japan in 1989 , around 250000 stayed at home, 100000 were in the special nursing homes for the aged, and 250000 were in hospital. ${ }^{10}$ The Japanese Ministry of Health and Welfare estimates that by the year 2000 the number of bedridden people in Japan will have reached 1 million. ${ }^{10}$

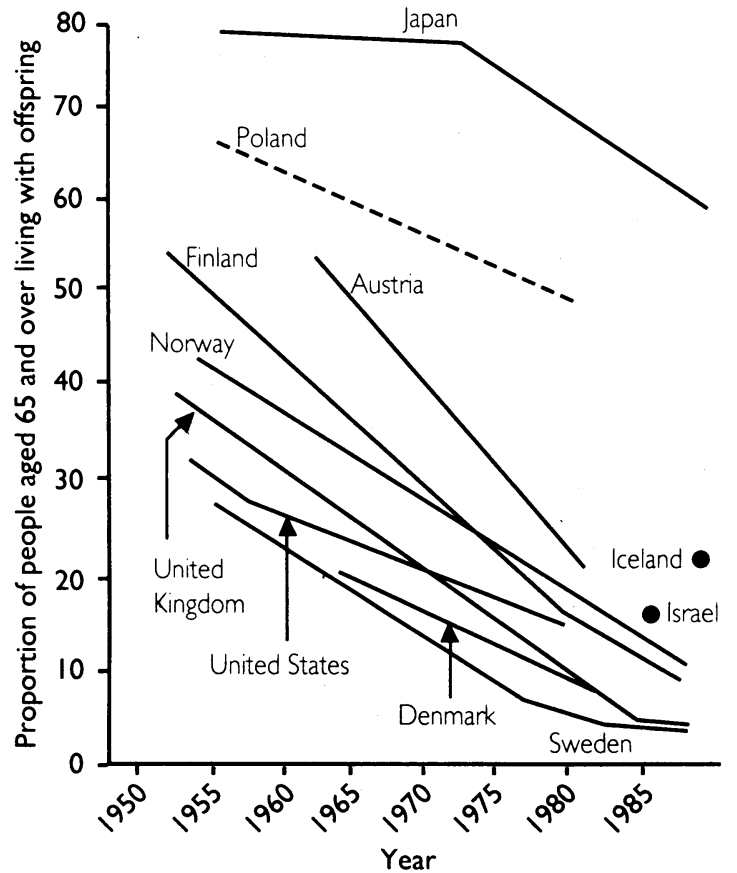

FIG 3-Percentages of people aged 65 and over who lived with their children. Data for selected countries, 1950-88. (Source: Professor $G$ Lundstrom, Institute of Gerontology, fönköping, Sweden) 


\section{Other problems}

Several problems remain, not least of which is the shortage of physicians and nurses in Japan. This is especially true in hospitals, where the ratio of nurses (qualified and unqualified) to inpatients ranges from $1: 2$ in the best hospitals to as low as $1: 6$ in the most basic hospitals for the elderly. This is no more than a quarter to a third of the level in Western countries (table III). ${ }^{13}$ In the past the shortage of nursing staff in hospitals was overcome by the compulsory participation of the family in the patient's care (one reason why the cost of personnel in medical facilities - and the cost of medical care in general in Japan - is low) (table IV). ${ }^{13-15}$ However, with insufficient skilled staff it is impossible to cope with rapidly advancing technology. This applies not only to general hospitals but also to hospitals for the elderly, which primarily are concerned with long term care. Hence disabled elderly patients may be kept in bed for prolonged periods, so becoming completely dependent.

TABLE III -Numbers of doctors and nurses per 100 beds in selected countries, 1989

\begin{tabular}{|c|c|c|c|c|c|c|}
\hline & Japan & $\begin{array}{l}\text { United } \\
\text { States }\end{array}$ & $\begin{array}{l}\text { United } \\
\text { Kingdom }\end{array}$ & France & $\begin{array}{c}\text { West } \\
\text { Germany }\end{array}$ & Sweden \\
\hline $\begin{array}{l}\text { No of doctors } / 100 \text { beds } \\
\text { No of nurses } / 100 \text { beds }\end{array}$ & $\begin{array}{r}8 \cdot 5 \\
18 \cdot 3\end{array}$ & $\begin{array}{l}18 \cdot 2 \\
55 \cdot 1\end{array}$ & $\begin{array}{l}20 \cdot 3 \\
40 \cdot 2\end{array}$ & $\begin{array}{l}29 \cdot 5 \\
69 \cdot 1\end{array}$ & $\begin{array}{l}22 \cdot 7 \\
29 \cdot 6\end{array}$ & $\begin{array}{l}19 \cdot 3 \\
61 \cdot 9\end{array}$ \\
\hline
\end{tabular}

Source: Sugaya et al..$^{12}$

TABLE IV-Size of health sector

\begin{tabular}{lccc}
\hline & $\begin{array}{c}\text { \% Of gross } \\
\text { domestic product } \\
\text { spent on total } \\
\text { health } \\
\text { expenditure } \\
\text { (data for 1984) }\end{array}$ & $\begin{array}{c}\text { \% Of gross } \\
\text { domestic product } \\
\text { spent on public } \\
\text { health } \\
\text { expenditure } \\
\text { (data for 1984) }\end{array}$ & $\begin{array}{c}\text { \% Oll employed } \\
\text { people who work } \\
\text { in health care (year } \\
\text { available) }\end{array}$ \\
\hline United Kingdom & $5 \cdot 9$ & $5 \cdot 3$ & $5 \cdot 3(1983)$ \\
Japan & $6 \cdot 6$ & $4 \cdot 8$ & $2 \cdot 9(1981)$ \\
Germany & $8 \cdot 1$ & $6 \cdot 4$ & $2 \cdot 2(1980)$ \\
Canada & $8 \cdot 4$ & $6 \cdot 2$ & $4 \cdot 8(1981)$ \\
France & $9 \cdot 1$ & $6 \cdot 5$ & $4 \cdot 4(1983)$ \\
Sweden & $9 \cdot 4$ & $8 \cdot 6$ & $7 \cdot 8(1983)$ \\
United States & $10 \cdot 7$ & $4 \cdot 4$ & $5 \cdot 3(1983)$ \\
\hline
\end{tabular}

Source: Organisation for Economic Co-operation and Development. ${ }^{14}$

Health care facilities in Japan are a legacy of attempts to meet the sharp rise in demand for medical care that occurred in the period after the second world war. The standard of living was low, which influenced the design of hospitals. In most hospitals, for example, floor area per bed is no more than $35 \mathrm{~m}^{2}$-that is, one third of that in the United States and Europe. Furthermore, hospitals lack enough communal toilets and bathrooms, and very few have rooms with a private toilet or bath (or even shower). Many hospital wards are very unattractive, matters like renovation being ruled out by lack of spare space in the design. It is also fairly usual to have six to eight patients to a room, so that overcrowding is common. Of all 1.64 million beds in hospitals in $1991,5.8 \%$ were in private rooms and $3.9 \%$ in semiprivate rooms. ${ }^{16}$

Overall the environment for medical care in Japan is poor. Standards were set when hospitals were concentrating on acute medical problems. Medical care consisted in applying technology while ignoring patients' other needs. Cramped, ill equipped, and uncomfortable surroundings in which to receive treatment were to some extent compensated by the patient having members of his or her family in attendance as compulsory care givers.

\section{Future of long term care for the elderly}

Japan is now reviewing all aspects of the social welfare and medical care of its elderly people in order to decide the direction of future development. As in other advanced industrialised nations many elements of long term care include long term financial aid, so that social welfare is inseparable from the medical care service.

There are two main ways of providing a long term care service (institutional and home care) for elderly people-(a) commercially, as controlled by market mechanisms; and $(b)$ by social services with public money. Limitations of the first method are evident in the United States. There the cost of services is so high that many elderly people fall into poverty. The most important advantage of a commercial supply should be the elimination of inferior services by competitionbut this does not work in the United States, where excessive demand results in some extremely unsatisfactory services. ${ }^{17-23}$ Furthermore, a complicated and diverse service supply system is more expensive overall and results in higher premiums for users. ${ }^{24}$ This leads to deterioration in the quality of services and dissatisfaction among users. Hence this method may encourage limitless growth in the need for these services and result in unendurable costs for many households.

Scandinavian countries provide a very high standard of long term care for elderly people funded by the social services with public money. But such a system cannot be introduced in Japan at present because of deficiencies in its social security system. Nevetheless, the funding of long term care of disabled elderly people in Japanboth at home and in special facilities-has improved substantially and exceeds the limits possible by families.

Recently in Japan it has been voiced publicly that long term care of the elderly should be the responsibility of government. Though the various alternatives are accepted to some extent and are practical and efficient, facilities are in short supply and cannot cope as life expectancy rises. Japan is facing a crisis in the long term care of its elderly citizens and a solution is required urgently.

1 Yamamoto M, Yoshiba K, Horiuchi S, Izumi Y. Shobyotokei kara mita nosochu. Journal of Health and Welfare Statistics 1989;36:13-22.

2 Shimamoto To, Komachi $\mathrm{Y}$, Inada $\mathrm{H}$, et al. Trends for coronary heart disease and stroke and their risk factors in Japan. Circulation 1989;79:503-15.

3 Shiraishi M. Hyojunkashiboritsu ni tsuite. Fournal of Health and Welfare Statistics 1986;33:200-56.

4 Tsuneta Yano Memorial Society. Nippon: a charted survey of fapan 1990/91. Tokyo: TYMS, 1992

5 Charlton JRH, Velez R. Some international comparisons of mortality amenable to medical intervention. BMF 1986;292:295-301.

6 Marmot MG, Smith DS. Why are the Japanese living longer? $B M \mathcal{J}$ 1989;299:23-30

7 Igleheart JK. Japan's medical care system (part 1). N Engl f Med 1989;319: $807-12$.

8 Igleheart JK. Japan's medical care system (part 2). $N$ Engl J Med 1989;319: $1166-72$.

9 Health and Welfare Statistics Association. Patient survey. Fournal of Health and Welfare Statistics 1989;36 (No 4):91-2.

10 Ministry of Health and Welfare. Annual report for 1990-91. Tokyo: Ministry of Health and Welfare, 1992.

11 Hasegawa T, Inoue $M$. Iryohi kara mita nosochu. Journal of Health and Welfare Statistics 1990;36:23-31.

12 Ministry of Health and Welfare. Netakiri zero o mezashite. Tokyo: Ministry of Health and Welfare, Chuo Hoki Shuppan, 1989.

13 Sugaya Y, Matsui M, Kawaguchi T Nihon no iryo to obei no iryo no hikaku. foumal of Health and Welfare Statistics 1990;137:8-13.

14 Organisation for Economic Co-operation and Development. Financing and delivering health care - a comparative analysis of OECD countries. OECD Social Policy Studies 1987; No 4:37-8

15 Shieber G, Poullier JP. International health care expenditure trends: 1987 Health Aff 1989; Fall: 169-77.

16 Shakai Hoken funpo fournal 1991; No 1742:28-9.

17 Pegles CC. Health care and the elderly. Rockville, Maryland: Aspen Systems, 1981.

18 Mundingwer MO. Home care controversy. Rockville, Maryland: Aspen Systems, 1983.

19 Okamoto Y. America no inyo to kango. [American medicine and nursing.] Tokyo: Hoken Dojin, 1984.

20 Menderson MA. Tender loving greed. New York: Vintage Books, 1975

21 Vladeck BC. Unloving care-the nursing home tragedy. New York: Twentieth Century Fund, 1980.

22 Hiatt $\mathrm{HH}$. America's health in the balance: choice or change. New York: Harper and Row, 1987.

23 Hendrics J, Hendrics CD. Aging in mass society-myths and realities. Boston: Little, Brown and Co, 1986

24 Andersen BR. Reflections after visit to Japan. Koseifukushi fournal 1990; No 3841:2-10.

(Accepted 12 May 1992) 